UC-NRLF

$$
25
$$




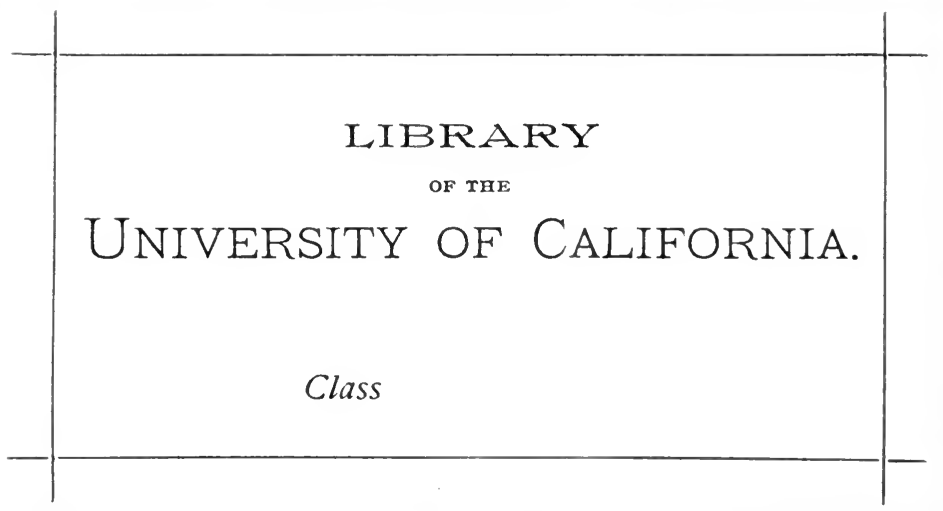




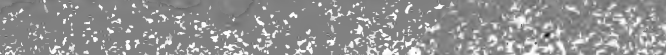

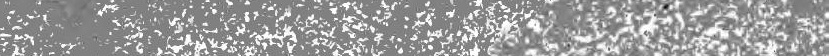

$\therefore$ a

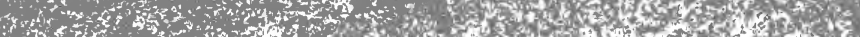

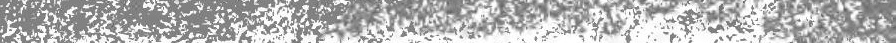

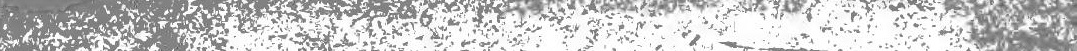

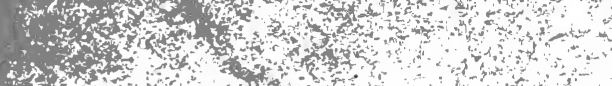

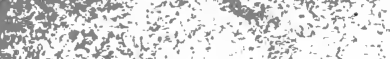

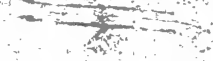

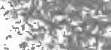
$x^{2}+\cos ^{2}$

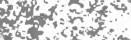
Ats

ins

$x_{x \rightarrow 2} x_{x \rightarrow 2}=0$

$\mathrm{H}^{2}=\mathrm{I}^{2}=2$

int

$4 x^{2} x^{2}$

-

2.

$42 \frac{2}{20}$

in

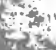

its

sis?

and son Sontorin

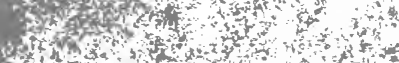
$8)$<smiles></smiles>
Fing ond (a) $+12=0$

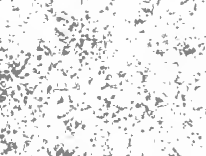
forition tiving $7 x+3=<5$ tis $15+2$ os 3 -

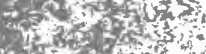
40 and site of

$$
\text { and }
$$

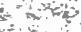

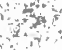

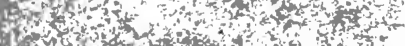

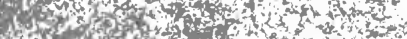

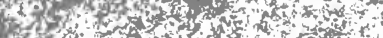

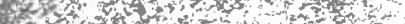

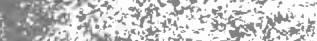

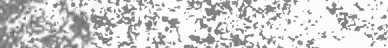

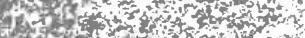

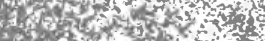

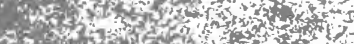

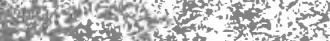

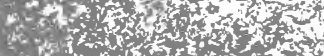

2

$0+x^{2}$

is

sin

5 th 


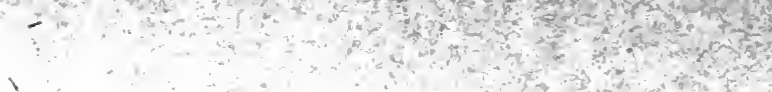

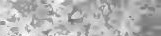

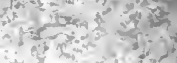
$x^{3} x^{2}=3$ 4
4
4 


\section{CAMDEN MISCELLANY}

\section{VOL. XII}

CAMDEN THIRD SERIES

V O L. X V I I I

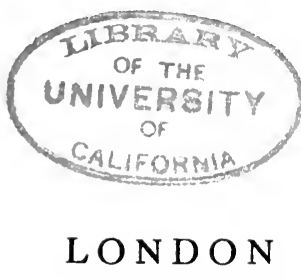

OFFICES OF THE SOCIETY

$6 \& 7$ SOUTH SQUARE

GRAY'S IN N

I 9 I 0 
GENERAE

PFIn VICALA 


\section{CONTENTS}

TWO LONDON CHRONICLES, FROM THE COLLECTIONS

of John Stow. Edited by C. L. Kingsford, M.A., F.S.A., F.R.Hist.S.

LIFE OF SIR JOHN DIGBY (I605-1645). EDITED bY Georges Bernard, Lets

ITER BELliCOSUM: Adam Wheeler his Account of 1685. Edited by H. E. Malden, M.A., Hon. Fellow of Trinity Hall, Cambridge, V.-P. and Hon. Sec. R.Hist.S.

COMMON RIGHTS AT COTTENHAM AND STRETHAM IN CAMBRIDGESHIRE. EDITED BY W. Cunningham, D.D., F.B.A., President of the Royal Historical Society and Archdeacon of Ely . . 


\section{Digitized by the Internet Archive in 2007 with funding from Microsoft Corporation}




\section{ITER BELLICOSUM I 685}




\section{TER B E L L I COS U M}

A D A W HEELR

HIS ACCOUNT OF I 685

E DITE D FOR THE

ROYAL HISTORICAL SOCIETY

B Y

HENRY ELLIOT MALDEN, M.A.

HON. FELLOW OF TRINITY HALL CAMBRIDGE

VICE-PRESIDENT AND HONORARY SECRETARY

OF THE ROYAL HISTORICAL SOCIETY

CAM DEN M ISCELLA N Y

V O L. X I I

L O N D O N

OFFICES OF THE SOCIETY

6 E 7 S O U T H S U A R

GRAY'S I N N

I 910 


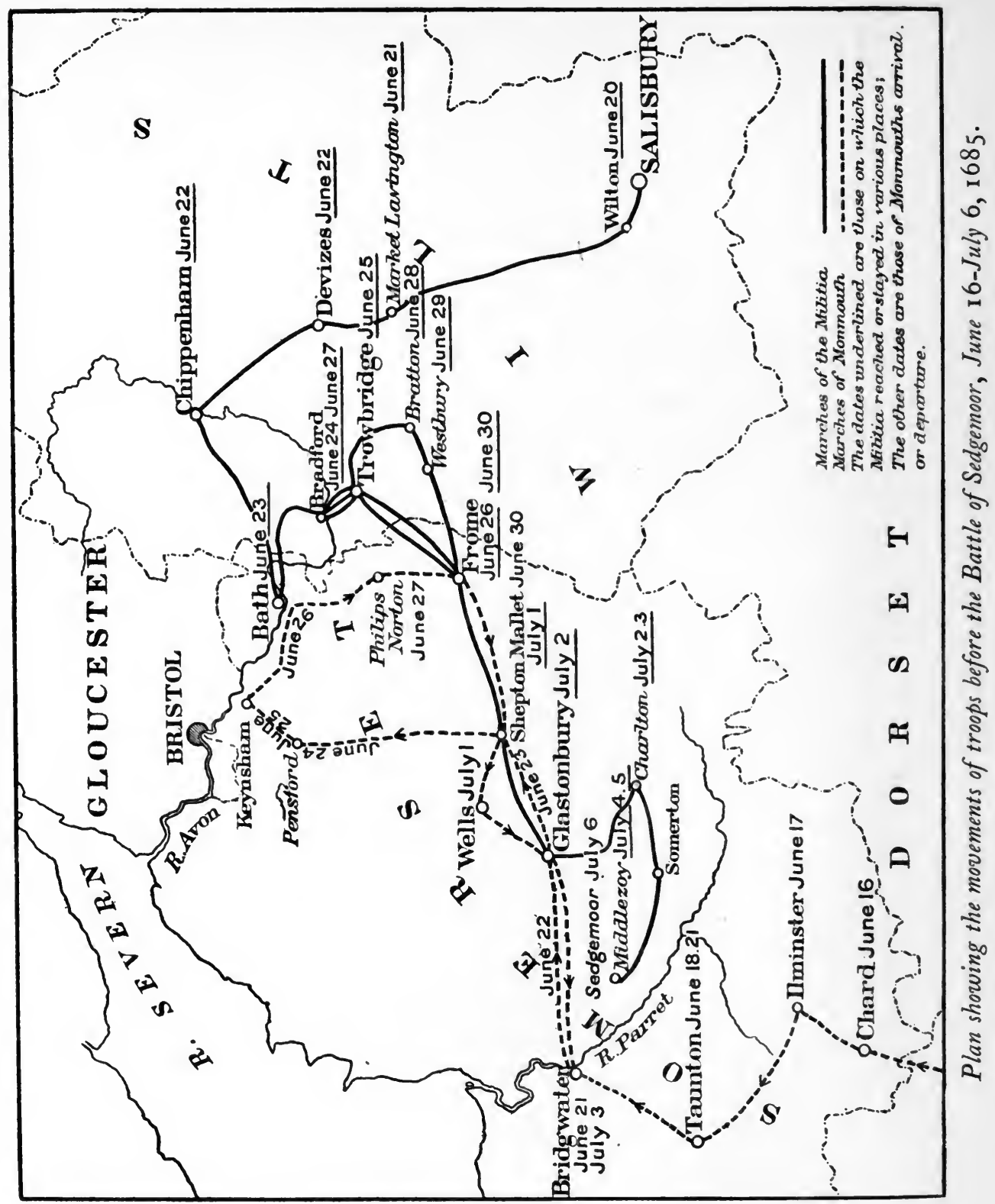




\section{P R E F A C E}

This MS., called on the outside "Adam Wheeler, His Account of 1685," was found in Corhampton House, Bishop's Waltham, Hampshire, by Mr. A. R. Malden of Salisbury, M.A., Trinity Hall, Cambridge. It has been put into the hands of the Society by the kindness of the owner, Mrs. Campbell-Wyndham-Long. The history of the writer has not been recovered. Adam Wheeler occurs in the rate-book of St. Edmund's parish, Salisbury, in 1661, but is more likely to be this Adam's father than himself. He was a man of some education, who not only could write and spell but could quote Virgil, Sic vos non vobis, and could compose two very indifferent Latin elegiac couplets. Very possibly when not drummer to the Wilts Militia he was a Schoolmaster. He seems to have been rather specially attached to Colonel Wyndham, for whom no doubt he wrote the account. This was John Wyndham, of Norrington, M.P. for Salisbury in 1681 and 1685, father to Thomas, created Lord Wyndham, Chief Justice of the Common Pleas. His direct male line is extinct, but he was a relative of the owner of the MS.

Evidently Wheeler put down some matters as they occurred; for instance his enumeration of the prisoners marched by his regiment was made then and there upon the top of his drum. The account was written up generally after the campaign. The dates are wrong at the beginning. He starts on Wednesday, June 16th, but June 16th in 1685 was a Tuesday. His days of the week are 
more likely to be right than his days of the month. On what he calls Saturday June 19th, really the 20th I believe, the regiment marched from Salisbury to Wilton. They left Wilton in the afternoon of what he calls Sunday the 20th. He does not mention going to church in Wilton, probably they did; at any rate he would know that it was Sunday morning when they were there. We may take it therefore that the Regiment was first called together on Wednesday June 17th. On the previous Monday the Lord Lieutenant, the Earl of Pembroke, had come to Salisbury, for the Churchwardens' account of St. Thomas' shew 6/- for ringing the bells for his arrival. Two days later is full short time for his forces to be mobilised. On the day when they assembled Monmouth, who had landed at Lyme on the 11th, was at Ilminster. On Saturday June 20th when they marched to Wilton, Monmouth was at Taunton. The clates are wrong by a day till they came to Frome on what he calls the 29th; then 30 appears in the margin, and on Wednesday July 1st they march from Frome to Shepton Mallet, the dates henceforth being correct.

The general reasons for the marches appear fairly clear, if we consider the movements of the enemy. On the afternoon of June 21st and on June 22nd, they made long marches from Wilton to Market Lavington, thence to Devizes and Chippenham. On the 23rd they went to Bath. Monmouth in these days was marching from Taunton to Bridgewater, Glastonbury and Shepton Mallet, evidently aiming at Bristol, or at least a passage of the Avon. Churchill had only a few regulars yet on the spot; and the Militia, though not highly trusted, might be necessary for want of better troops. On the 24th Monmouth was at Pensford, and the Militia marched to Bradford. Circumstances had altered. Feversham was at Bath on the 24th, some cavalry had been pushed on to Bristol, and the main force of the regulars was closing up. They concentrated about Bath on the 26th. There was some idea in Monmouth's army of a dash into Wiltshire as an alternative to attacking Bristol, and at Bradford the Wilts Militia guarded their own frontier, and the Royal Artillery which was still at 
Devizes. " On the night of the 24th-25th there was "an alarum." There was no enemy; but between Wheeler's lines I think we may read that the regiment ran away in the dark. By reason of "the alarum" they did not unite into a body till they came to Trowbridge the next day. On the 26th the Earl of Pembroke made a dash on Frome with some of his Militia, not Wheeler himself, and came back with prisoners and scythes set on poles, murderous weapons of which the drummer disapproved. On the 27th Monmouth beat off an attack under the Duke of Grafton at Philip's Norton. The Wilts Militia were drawn up with other troops in support, in case the rebels should attack in turn. Monmouth however retreated, and the whole royalist force followed slowly.

The Militia were not actually under fire at Sedgemoor. They seem to have turned out at "the alarum" more promptly and steadily than the Bradford experience might have shown to be probable, and were complimented on their smartness. They were well commanded, and not allowed to break their ranks for plunder after the battle. The prisoners were led by them to Weston Zoyland Church, and were counted and described by Wheeler. He says 228 in all, but he really counted 238. The Parish register of Weston Zoyland gives another estimate of prisoners and of losses. No doubt some prisoners were brought to the church another way. This account is as follows:- "An account of the fight that was in Langmoor. " The ingagement began between one and two of the clock in the morning. It was continued near one hour and a half. Their was killed upon the spot of the King's souldiers sixteen, and five of them buried in the churchyard, and they all had Christian Buriall. One hundred or more of the King's souldiers wounded, of which wounds many died; of which we have no certain account. Their was killed of the rebels upon the spot about 300 ; hanged with us 22 , of which 4

1 See Lord Wolseley's Life of Marlborough, vol. i, Ch. 37. But the reader must observe that Lord Wolseley's dates are as muddled as Wheeler's.

The battle was on Langmoor, not on Sedgemoor properly so called. 
weare hanged in gemmaces. About 500 prisoners brought into our church ; of which there was 79 wounded, and 5 of them died of their wounds in our church."

Feversham writing to Sunderland, directly after the battle, says that he lost not 50 killed and about 200 wounded.' Of Officers and men 208 survivors were compensated for wounds in the campaign. ${ }^{2}$ The Wilts Militia lost two men in the campaign, by accidents. The bells of St. Thomas' Salisbury were rung, at a cost of five shillings, "when Colonel Wyndham came home from the Army," and no doubt Wheeler shared his triumph.

H. E. M.

${ }^{1}$ Hist., MSS. Comm., Ninth Report, p. 2 I.

2 Col. McKinnon, Origin and services of the Coldstream Guards. 


\section{$A n^{\circ} j^{\circ}$ Jacobi Scđi, Rs. \\ I TER BELLICOS U M \\ O R}

A PERFECT RELATION OF THE HEROICK

MARCH OF HIS MAT ${ }^{\text {ies }}$ TRUELY LOYALL SUBJECT AND MAGNANIMOUS SOULDIER COLONELL $\mathcal{F O H N}$ WINDHAM ESQRE. WITH HIS REGIMENT OF FOOTE

INTO THE WESTERN PARTS OF ENGLAND FOR

THE SUPPRESSING OF $\mathcal{F}$ AMES SCOT AND HIS

ACCOMPLICES IN THEIRE REBELILIOUS

INSURREC'TION. TOGETHER WITH

SOME REMARKABLE OCCUR-

RENCES HAPPENING IN

THAT EXPEDI'TION.

Failhfully set down by Adam Wheeler

one of the Drums of his Honors, owne Company.

$A n^{\circ}$ Chrsi $^{t i} 685$.

Being Wednesday ${ }^{1}$ I was summoned by a Coinand from his 1685.

Honor to appeare in the Market-Place of New Sarm in the June 16.

County of Wilts by eight of the Clocke in the Morning in his Regiment compleatly armed according to my place as a Drum. Where the Regiment being drawne together was dischardged till the next Morning. When againe met, being the Seventeenth day. They were dischardged untill Fryday the eighteenth of June; and ye nineteenth being Saturday ; ${ }^{2}$ The Regiment was exactly com-

1 June I6th was Tuesday.

2 Saturday was June zoth. 
pleated by his Honor and accomodated fitt for Warre according to Military Discipline, and that day by his Comand, about sixe of the clock in the Evening, the Drums beating and the Colours displayed, leaveing the Citty wee directed oure March to Wilton, beinge about Two Miles distant and Quartered there that night; where his Hono $^{r}$ ordered his Carridge and Amunic̃on to be brought to him.

June 20. The next day being Sunday ${ }^{1}$ on $\mathrm{w}^{\text {ch }}$ day in the Afternoone leaveing the Towne of Wilkton (sic), we continewed oure March to Market Lavington.

June 21. Early the next morning his Hono ${ }^{\mathrm{r}}$ marched to the Devizes, and there refreshed his Regim ${ }^{t}$ for the Weary and hard Afternoones March they sustained the day before.

In the Afternoone by Beate of Drum the Regim ${ }^{t}$ marched as farre as Chippenham and June the 22, being Tuesday, ${ }^{2}$ They marched from Chippenham to the Citty of Bath, where They Quartered that night.

June 23. The Regim ${ }^{t}$ leaveing the Citty of Bath went as farre as Bradforde. That Night being very darke there was an Alarum. By reason of which the Regim $^{t}$ could not unite into a Body till They came to Trowbridge, $w^{\text {ch }}$ was

June 24. Where, for the better security of his Honors Carridge, I desired some assistance being Resolued to hazzard my Life by Ball or Sword, rather than loose any part thereof here the whole Regim ${ }^{t}$ lay.

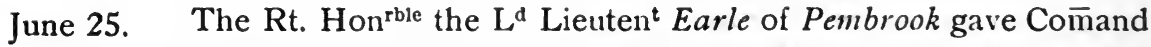
for some of the Regim ${ }^{t}$ and some of the Militia Horse to goe $\mathbf{w}^{\text {th }}$ him to Froome, Where he forced the Rebells to lay downe theire Armes, and brought away with him the Constable of that Towne to Trowbridge who proclaymed the Duke of Monmouth King, and severall cruell and New invented murthering Weapons as Sithes and ye like.

1 Probably Sunday June 21 st.

2 Tuesday was June 23 rd. 
Here There was One of the Colonells Regim ${ }^{t}$ belonging to Lieuten $^{\text {t }}$ Colon $^{\text {II }}$ Yong accidentaly hurt by dischardgeing a Musquett which rent his hand in peeces, and soe became the Occasion of his Death, for he liued not many daies after.

We continued our march from Trowbridge to Kingsdowne, June 26. where divers other Regim ${ }^{\text {ts }}$ met here his Honors Regim $^{\text {t }}$ was by his Grace the Duke of Grafton and the $\mathrm{R}^{\text {th }}$ Hon $^{\text {rble }}$ the Earle of Feversham set in Batalia, as if presently to engage the Enemy. Thence we marched to Bath.

From Bath the Regim ${ }^{t}$ was led by his Honor Coll Windham June 27. to Trowbridge, Where They made noe stay but Marched forwards into Bratton Lane, and there by an Alarum of the Enemies being neere caused the Regim ${ }^{t}$ to incampe in that Landsend, and the Blew Regim ${ }^{t}$ alsoe, and the yellow Hampshire Regim ${ }^{t}$ encamped in a ground neere the said Lane.

The Regim ${ }^{t}$ marched into Bratton Fields, and was there drawn June 28. up, and after some small stay moved to Westbury. and thence directed its March neere to Froome; Where his Honors Tent was erected, and wee encamped there in a certaine Ground neere the Towne.

Dislodging from thence, wee marched directly into Froome; June 29. Where the Kings Maties Gracious Pardon was proclaimed to all such as had taken up Armes against him, if in 8 daies They would come in and accept thereof. Some Persons onely excepted, who were therein mentioned.

Being Wednesday ${ }^{1}$ his Honors Regim $^{t}$ tooke theire March to Shepton Mallet; Here not farre from the Towne, a Ground was shewne which lay within Prospect, where Monmouth and his Army was drawne up and exercised. ${ }^{2}$

1 Correct date.

2 Monmouth was that day retreating to Wells. It means where his army had been drawn up, not that it was then there. But the armies had come very close together on July 1, 2, and if Churchill had been in command Sedgemoor would have been anticipated by four days. 
July 2. Being Thursday we marched from Shepton Mallet to Glastenbury, and from thence wee removed and went fowards Sumerton. In which March wee had the sight of Kings Sedgemoore being about One Mile distant from us; And here Wee received a Comand to Returne and March back to Charleton.

July 4. From whence wee Marched to Kings Sedgemoore, marching Eight Miles in the Moore soe farre as Middlesey; Where being Alarumed;

July 6. The $\mathrm{Rh}^{t}$ Honorble The Earle of Pembrooke Lord Lieuten in great hast came rideing to the house where his Honor Colon" Windham was quartered, it being betweene Twelve and One of the Clock in the Mornening, calling out Colon Windham Colon "Windham the Enemy is Engadged, and askeinge for his Drums; The Colon ${ }^{11 s}$ answer was that he was ready, and soe forthwith prepared himselfe.

There being then noe Drum in the house but Adam Wheeler, who opened the doore and answered his Lorsh ${ }^{p}$ that he was ready to obey his Comand; Soe his Lor immediately comanded him to beate an Alarum, $w^{\text {ch }}$ he presently performed.

(Although some of the Regimt did encleavor to have the Credite of that peece of Service ascribed to Themselves; One saying it was I that did first beate the Alarme; Another in like manner saying the same, soe that Wheeler may iustly complaine as the Poet Virgil dicl concerneing his, Sic vos non vobis, and somewhat after The same manner as he spoke, superscribe, Hos Ego Versiculos feci tulit alter honores.)

When the Alarum was beaten by Adam Wheeler in Middlesey according to the Lord Lieuten ${ }^{\text {ts }}$ Comand; The Regim ${ }^{t}$ marched through Weston into Weston Moore with as much expedic̃on as possible could be, where They were drawne up Three deep in order to engadge if Occasion required.

The Aforesaid Sixth of July, the Fight began very early in the morneing which Battell was over within the space of Two Howers, and the Enemy received a totall Rowte.

Here Adam Wheeler (being then at his Post) was one of those 
of the Right Wing of his honor ${ }^{r}$ Colon" Windham's Regim ${ }^{\text {t }}$ who after the Enemy began to run desired Leave of his Honor to get such Pillage in the feild as they could finde; But his Honors Answer and Comand was; That uppon Paine of Death not a Man of his Regim ${ }^{t}$ should move from his Post saying; That if the Enemy should rally together againe, and the Regim ${ }^{t}$ be in disorder, every man of them might loose his Life.

The Battell being over the Right Honor ble the Earle of Feversham, Generall of his Maties Army, came to the Head of Collon ${ }^{1 / s}$ Windhams Regim $^{\mathrm{t}}$ and gave him many Thanks for his readynesse, Saying, his Matie should not hear of it by Letter, but by Word of Mouth ; and that he would certfy the Kinge himself of it.

An Account of the Prisoners that were brought along by the Right Wing of his Honor Colon ${ }^{\text {ll Windhams Regim }}{ }^{\mathrm{t}}$ to Weston Church as they were tyed together: Adam Wheeler writeing them downe on his Drumhead as they passed by.

The first Number was Fifty and five, most of them tyed together.

The Second Number was thirty and two tyed in like manner.

The Third was Two wounded in theire Legs, crawling uppon the Ground on theire Hands and Knees to Weston Church.

The Fowerth was Thirty seven in number, many of them tyed and pinnackled together.

The Fifth was One alone being naked, onely his Drawers on.

The Sixth was One Single one more.

The Seventh was One more running, being forced along by Two Horse Men with Blowes, and rideing close after him.

The Eighth Number was Fowerteene most of them being tyed together.

The Nineth was Forty Seven most of them tyed as the former, such of Them as had a good Coate or any thinge worth the Pilling, were very fairely stript of it.

The Tenth Number was Eight tyed by Two together Arme to Arme.

The Eleventh was, Twelve tyed and pinnackled. 
The Twelfth was Seventeene tyed and pinnackled as the former.

The Thirteenth One more.

The Fowerteenth in Number were Seven more.

The Fifteenth, One more.

The Sixteenth, One more.

The Seventeenth was One more, Hee was very remarkeable and to be admired, for being shot thorow the shoulder and wounded in the Belly ; Hee lay on his Backe in the Sun stript naked, for the space of Tenne or Eleven Howers, in that scorching hot day to the Admiration of all the Spectatours ; And as he lay, a greate Crowde of Souldiers came about him, and reproached him, calling him, Thou Monmouth Dog How long have you beene with youre Kinge Monmouth? His answer was, that if he had Breath, he would tell them: Afterwards he was pittyed, and they opened round about him, and gave him more Liberty of the Aire, and there was One Souldier that gave him a paire of Drawers to cover his Nakednesse: Afterwards haveing a long Stick in his hand he walked feably to Weston Church, where he died that Night, and two wounded men more.

The Number of the Prisoners that were led by the Right Wing of his Hono ${ }^{\text {rs }}$ Regiment did amount to 228. ${ }^{1}$

The Country men that gathered up the Dead slayne in this Battell gave an Account of the Minister and Church Warclens of Weston of the Number of One Thousand Three hundred Eighty and Fower; Besides many more they did beleeve lay dead unfound in the Corne.

Where Adam Wheeler saw of dead Men lying in One Heape One Hundred Seventy and Fower ; which those that were digging a Pit to lay them in gave the Number of. ${ }^{2}$

From Weston Moore the Regim ${ }^{t}$ marched to Weston, and thence to Middlesey, and from Middlesey againe to Weston, and thence to Weston Moore: Where a Dutch Gunner, and a Yellow-

1 The total is in fact 238

2 There used to be a mound, now levelled, near what had been the left wing of Monmouth's army, where the men were buried. 
coate Souldier that ran out of his Maties Army to Monmouth were hanged on a Tree in Weston Moore not farre from the Church.

This Day Adam Wheeler went into the Campe and tooke an Account as neere as hee could of his Matie Carridges and Great Guns where were neere One Hundred and forty of them : Of these there were nineteene Guns some haveing sixe Horses. Some seven, and some eight Horses a peece to draw them.

Here his Honor Coll ${ }^{l}$ Windham received Orders to Guard his Matie Guns and Carridges with his Regim ${ }^{t}$ : from Weston Moore to the Devizes, it being a peece of service of noe small Trust and Credite, and soe much his Honor was pleasd to informe his Souldiers of.

This Afternoone an Accident fell out to be lamented: One of His Hono ${ }^{\text {rs }}$ owne Souldiers, being in Exercise, and quitting his Armes, A musquett went off as it lay on the Ground, and shot him thorow both of his legs, soe he died in a short time after.

From the Camp in Weston Moore his Honor Coll Windham marched with his Regim ${ }^{t}$ to Glastenbury: Heere at the signe of the White Hart a Duell was fought betweene Captaine Love and Major Talbot. The Major fell, and Captain Love fled for it.

Heare alsoe were sixe men of the Prisoners that were taken hanged on the Signe Post of that Inne, who after as They hung were stripped naked, and soe left hanging there all night.

Here Alsoe at this towne of Glastenbury there was an Alarm, where uppon the Regim ${ }^{t}$ was comanded to the Abby Cloyster.

His Hono ${ }^{\text {rs }}$ Regim $^{t}$ Marched from Glastenbury (where those sixe men were left hanging on the Signe-Post) to Wells; Thence they marched to Embetch and soe to Philips Norton.

The Regim ${ }^{\text {t }}$ left Philips Norton, and Marched to the Devizes (guarding his Maties Carriages and Guns where his Hono was dischardged of that Trust And here his Honor dischardged the Regim $^{t}$ likewise, till the next Summons by Beate of Drum.

July 8 . 
166 ITE R BELLICOSUM

July 9. This is the best account I can give yor $\mathrm{Hono}^{\mathrm{r}}$ of that successfull March : and doe humbly beg yor Hono $^{\text {rs }}$ pardon for this Presumption, and with leave subscribe my selfe Sir,

Yor Honors most dutifull Drum, and most humble and Obedient Servant,

Adam Wheeler.

Anglorum vivat semper Prolesque Jacobi, Rex : fugiant Hostes non remorante pede.

Atque diu vivat stirps Nobilis inclyta Wyndham

Detque Deus pueris Gaudia Multa suis. 


\section{INDEX}

B

Bath, I54, I60, 16 .

Bradford, 154, I55, 160.

Bratton Fields, I6I.

Bratton Lane, I6r.

Bridgewater, 154 .

Bristol, 155 .

C

Charleton, 162.

Chippenham, 154, 160.

Churchill, Lord, I54, I61.

\section{$\mathrm{D}$}

Devizes, I54, I55, I64, I65.

E

Embetch, 165 .

\section{F}

Feversham, Earl of, $154,156,161$, 163 .

Frome, 154, 155, 160, I6I.
G

Glastonbury, 154, 162, I65.

Grafton, Duke of, 155, I6r.

I

Ilminster, I 54 .

K

Kingsdowne, I6r.

L

Langmoor, 154 .

Love, Capt., 165.

Lyme, I54.

\section{M}

Market Lavington, I60.

Middlesey, I62, I64.

Monmouth, Duke of, I54, 160, 161 .

\section{N}

New Sarum, 159. 
$\mathbf{P}$

Pembroke, Earl of, 154, 155, 160, 162.

Philips Norton, 155, 165.

Prisoners, list of, 163,164 .

\section{S}

Salisbury, I 54, 159 .

Sedgemoor, 162.

Shepton Mallet, 154, I61, 162.

Summerton, 162.

\section{$\mathrm{T}$}

Talbot, Major, 165.

Taunton, 154.

Trowbridge, 160.

\section{W}

Wells, 165 .

Westbury, I6I.

Weston Church, $163,164$.

Weston Moor, I62, 164, I65.

Weston Zoyland, 155, 162.

Wheeler, Adam, I53, I62, I63, $165,166$.

Wilton, $154,160$.

Wyndham, Colonel, 153, 156, 161, $162,163,165$.

Wyndham, Lord, 153.

\section{Y}

Yong, Colonel, 161. 
C OMMON R IGH T S A T COTTENHAM $\mathscr{6}$ STRETHAM IN CAMBRIDGESHIRE 
